\title{
Pengalaman Klien Sedang Menjalani Pengobatan MDR-TB
}

\author{
Wirda Y. Dulahu, Siska Wati Ladiku \\ Program Studi Ilmu Keperawatan, Universitas Negeri Gorontalo \\ E-mail: wirda@ung.ac.id
}

\begin{abstract}
ABSTRAK
MDR-TB merupakan masalah kesehatan yang penting dan segera ditanggulangi. Pengobatannya memerlukan waktu lama dimana jauh lebih sulit dari kasus TB biasa.Penelitian ini bertujuan untuk memperoleh pengalaman klien sedang menjalani pengobatan MDR-TB di Poli Paru RSUD. Prof. Dr. H. Aloei Saboe Kota Gorontalo. Jenis penelitian kualitatif dengan pendekatan fenomenologi deskriptif. Informan berjumlah 5 orang dan 1 orang informan kunci dengan cara purposive sampling. Pengumpulan data menggunakan metode indepth interview dan field note dengan metode analisa Colaizzi. Hasil penelitian menghasilkan 7 tema yaitu respon menolak, respon menerima, mengalami efek samping, kepatuhan, kesulitan dalam menjalani pengobatan, dukungan yang diterima dan harapan untuk mencapai kesembuhan setelah menjalani pengobatan MDR-TB. Simpulan respon menolak akhirnya mereka memahami sehingga menerima dalam menjalani pengobatan MDR-TB. Efek samping dari obat MDR-TB memberikan dampak positif dan negatif terhadap tubuh. Kepatuhan informan mempertahankan pengobatan MDR dengan mendapatkan dukungan dari keluarga dan petugas pelayanan kesehatan. Kesulitan jarak pelayanan kesehatan, aktivitas terbatas, stressor sosial dan keuangan menyebabkan seluruh aspek kesehatan semakin terpuruk yang mempengaruhi kualitas hidup. Harapan bisa kembali bekerja untuk menanggung ekonomi keluarga dan menuntaskan pengobatan. Saran sebagai dasar intervensi bagi petugas kesehatan guna meningkatkan kualitas hidup klien MDR-TB.
\end{abstract}

Kata kunci: Pengalaman MDR-TB

\begin{abstract}
MDR-TB has been among the health issues that require an immediate treatment. This is because the treatment takes a long time and is more complicated rather than other TB cases. This study aims to explore the patients' experience during the treatment of MDR-TB at pulmonary clinic Prof. Dr. Hj. Aloei Saboe Regional Public Hospital, Gorontalo City. This qualitative research employed descriptive phenomenology approach. There were five people involved as the informant of this study and additional one person served as the main informat. They were selected by using purposesampling method. Furthermore, the data wee collected by applying in-depth interviewand field not with Colaizzi analysis. The result reveal seven themes from the respondets, e.g., rejecting, accepting, experiencing side effect, obedient, experiencing difficulty during the treatment, support, as well as hope to recover from the medication. It is inferred that in response to rejection, the patients are finally accepting their condition and starting the process of MDR-TB medication immediately. The side effect of the treatment consists of positive and negative impacts on the patients' body. Furthermore, the obedience of the patients to maintain the treatment is supported by the family and the healthcare assistants. Problems, such as the difficulty to reach a medical center, limited activities due to the disease, social stressor, and financial issue result in a drop in the health of the patients by which affects the patients' lives as well. The will of the patients to fully recover promotes the patients' spirit to work for their family. The suggestion of this present study serves as the basis of the interventions for the healthcare assistant to improve the condition of the MDR-TB patiens'.
\end{abstract}

Keywords: MDR-TB cases

\section{PENDAHULUAN}

\section{Fenomena penyakit MDR-TB}

(Multidrugs Resistant-Tuberculosis) telah menjadi masalah kesehatan masyarakat yang sangat penting dan segera ditanggulangi. Pengobatannya jauh lebih sulit dari Tuberkulosis (TB) biasanya, sehingga segera diidentifikasi dengan jelas agar pengobatan dapat dilakukan dengan tepat. Pada pasien yang memiliki riwayat pengobatan sebelumnya, kemungkinan terjadi resistensi sebesar 4 kali sedangkan terjadinya MDR-TB sebesar 10 kali atau lebih dibandingkan dengan pasien yang belum pernah diobati. Pasien MDR-TB 
sering tidak memiliki gejala sebelumnya sehingga menularkan penyakitnya sebelum sakit (Burhan, 2010:12).

Menurut data World Health
Organization (WHO) tahun 2013
dilaporkan
dilaporkan bahwa terdapat 3,6\% kasus baru dan 20,2\% kasus yang sebelumnya diobati. Kasus yang terdeteksi 84.000 orang dengan konfirmasi MDR-TB. Lebih dari 77.000 orang dengan TB-MDR dimulai pengobatan lini kedua. Sedangkan tahun 2014 WHO melaporkan, 3,5\% baru dan 20,5\% dari sebelumnya diobati. Berarti diperkirakan 480.000 orang memiliki MDR-TB. Diperkirakan 300.000 kasus akan terjadi. 136.000 dari perkiraan 300.000 TB-MDR pasien yang baru terdeteksi.

Namun pada tahun 2015 WHO melaporkan MDR-TB meningkat 3\% pertahun. Secara global lebih dari 90 ribu Pasien TB terdapat di 81 negara, ternyata jumlah MDR-TB lebih tinggi dari diperkirakan. Pada tahun 2015, diperkirakan ada 480 ribu kasus baru MDR-TB dan tambahan 100 ribu orang baru memenuhi syarat pengobatan MDRTB dengan TB rifampisin.

Menurut Kemenkes RI (2015) penemuan data kasus MDR-TB Nasional tahun 2015 sebanyak 18 ribu kasus MDRTB diantaranya terduga 15.300, terkomfirmasi 1860 , dan yand menjalani pengobatan 1566 kasus MDR-TB. Di Provinsi Gorontalo angka kejadian MDRTB tahun 2015 sampai 2017 berjumlah 28 orang. Meninggal dunia 7 orang (Dinas Kesehatan Propinsi Gorontalo, 2017). Berdasarkan data klien positif MDR-TB dari Poli Paru RSUD. Prof. Dr. H. Aloei Saboe Kota Gorontalo 2016 sampai 2017 sebanyak 27 orang dan jumlah klien aktif menjalami pengobatan MDR-TB sebanyak 11 orang.

Pengobatan MDR-TB membutuhkan waktu lama selama 6 bulan setelah terjadi konversi biakan. Pasien mendapat obat oral setiap hari, dan suntikan diberikan 5 hari dalam seminggu. Pasien diupayakan bertemu dokter untuk berkonsultasi dan pemeriksaan fisik. Pasien dirujuk untuk pemeriksaan dahak follow up sekali setiap bulan dan sampel dibawah ke laboratorium rujukan. Pasien mungkin juga dirujuk ke laboratorium penunjang untuk pemeriksaan rutin lain yang diperlukan. (Kemenkes RI, 2014:32).

MDR-TB adalah pengobatan yang resisten terhadap rifampisin dan isoniazid atau tanpa obat anti tuberkulosis lainnya. Efek samping MDR-TB seperti kulit dan mata pasien nampak kuning, pendengaran berkurang (tuli), halusinasi, delusi/waham, bingung. Reaksi alergi berat yaitu Syok anafilaktik dan angionerotik edema, kemerahan pada mukosa seperti mulut, mata dan dapat mengenai seluruh tubuh (Nawas, 2010:5). Efek samping ringan dan sedang tanpa harus menghentikan pengobatan, seperti kemerahan (rash) ringan, neuropati perifer, mual muntah, diare, sakit kepala, gangguan tidur, depresi.

Ketaatan pasien TB dalam menjalani pengobatan berdasarkan penelitian bahwa pasien sering dibawah kondisi yang sulit dan tantangan yang berat. Kadang diluar kontrol mereka. Waktu yang lama adalah kendala yang sering dihadapi. Informasi yang tidak lengkap, tidak ada penjelasan yang terus menerus berpengaruh pada ketaatan pasien. Faktor-faktor yang sangat mempengaruhi yaitu kemiskinan 
khususnya terpaut dengan pembiayaan dan keuangan, keyakinan, sikap terhadap pengobatan, dukungan keluarga, kerabat, masyarakat, dan masalah stigma, kemajuan penyakit dan efek-samping (Hudoyo, 2010:ii).

Menurut penelitian kualitatif MDR-TB oleh Morris et, al (2013) tentang Social, economic, and psychological impacts of MDR-TB treatment bahwa beberapa pasien mampu mempertahankan TB pra-MDR mereka sampai batas tertentu, kebanyakan pasien melaporkan kehilangan identitas mereka karena ketidakmampuan mereka untuk bekerja, isolasi sosial, stigmatisasi dari keluarga dan teman. Didiagnosis TB-MDR dan pengobatan yang dijalani menimbulkan tekanan psikologis, sosial dan ekonomi yang signifikan pada pasien.

Hasil penelitian kualitatif lainnya oleh Xua B, et. All (2004) tentang Persepsi dan pengalaman pencarian layanan kesehatan dan akses terhadap perawatan TB-sebuah studi kualitatif di Provinsi Pedesaan Jiangsu China bahwa Pasien wanita dan lansia dianggap lebih enggan untuk mencari perawatan kesehatan dan mencari perawatan batuk dari stasiun kesehatan desa dari pada rumah sakit umum. Banyak pasien TB mengatakan bahwa mereka tidak mampu membayar biaya perawatan $\mathrm{TB}$, bahkan di mana layanan disubsidi.

Sejalan dengan penelitian fenomenologi Zhang (2010) tentang pengalaman mahasiswa dengan TB paru bahwa penyakit TB paru mempengaruhi mental mahasiswa berupa takut dan cemas pada awal menjalani pengobatan, bosan dengan pengobatan, khawatir pada pemeriksaan dahak pertama dan masa depan serta kurang mendapat dukungan yang kuat dari keluarga.

Sedangkan menurut hasil Penelitian fenomenologi oleh Rundi di Malaysia Timur tentang pengalaman rakyat Sabah dalam memahami Tuberkulosis bahwa 96\% partisipan tidak mengetahui penyebab TB $98 \%$ partisipan berpendapat TB menular dan yang dilakukan partisipan adalah mencari obat modern untuk menyembuhkan. TB juga mempengaruhi partisipan dalam segala aspek kehidupan seperti kehidupan psikososial, fisik, dan keuangan (dalam Rejeki, 2012:5).

Berdasarkan hasil wawancara yang pertama pada salah satu Klien Sedang Menjalani Pengobatan MDR-TB di Poli Paru RSUD. Prof. Dr. H. Aloei Saboe Kota Gorontalo (2017) pengalamannya selama menjalani pengobatan sangat buruk karena tidak ada dukungan dari keluarga yang tidak memperdulikan kesehatannya dan membuat pasien tidak bersemangat menjalani hidup lagi. Semua orang pasti merasakan efek samping berupa susah tidur, pusing, mual sampai muntah. Klien berharap, keluarga menerima kembali keadaan kesehatannya setelah sembuh. Hasil identifikasi awal klien MDR-TB terlihat lemah, letih, berat badan menurun, batuk kronis, dan defisiensi perawatan diri.

Hasil wawancara yang kedua pada klien sedang menjalani pengobatan MDRTB di Poli Paru RSUD. Prof. Dr. H. Aloei Saboe Kota Gorontalo (2017) yaitu selama pengobatan klien merasa takut, putus asa dan perasaan menolak. Awal menjalani pengobatan timbul efek samping seperti mual, muntah, sakit ulu hati, tidak nafsu makan, dada berdebar, susah tidur, tuli pendengaran dan perasaan ingin mati saja 
karena adaptasi awal mengkonsumsi obat. Harapan klien ingin sembuh total dan tidak ada pengobatan selanjutnya. Dari uraian diatas, peneliti tertarik untuk melakukan penelitian tentang pengalaman klien sedang menjalani pengobatan MDRTB di Poli Paru RSUD. Prof. Dr. H. Aloei Saboe Kota Gorontalo.

\section{METODE}

Penelitian ini dilaksanakan di rumah tempat tinggal partisipan yang menjalani pengobatan MDR-TB di ruang poli paru RSUD. Prof. Dr. H. Aloei Saboe Kota Gorontalo. Metode penelitian kualitatif dengan pendekatan fenomenologi deskriptif. Informan berjumlah 5 orang dan 1 orang sebagai informan kunci. Pengamblan sampel dengan cara purposive sampling. Pengumpulan data menggunakan metode indepth interview dan field note dengan metode analisa data Colaizzi Methode.

\section{HASIL}

\section{Karakteristik Informan}

Karakteristik informan dalam penelitian adalah lima partisipan sedang menjalani pengobatan MDR-TB di Poli Paru RSUD. Prof. Dr. H. Aloei Saboe Kota Gorontalo. Semuanya dengan jenis kelamin laki-laki. Usia informan yaitu antara usia tiga puluh tiga tahun sampai dengan enam puluh tahun. Semua informan menganut agama islam. Tingkat pendidikan informan adalah Sekolah Dasar sebanyak tiga orang, Sekolah Menengah Atas satu orang dan Sarjana satu orang. Pekerjaan Wiraswasta dua orang, Sopir satu orang, Petani satu orang dan Aparatur Sipil Negara (ASN) 1 orang. Informan semuanya berasal dari suku Gorontalo. Lamanya informan terdiagnosa menjalani pengobatan MDR-TB mulai dari dua bulan, tiga bulan, tujuh bulan dan 18 bulan. Wawancara dengan kelima partisipan dilaksanakan di rumah tempat tinggal mereka yang telah disepakati bersama mereka beberapa hari sebelumnya. Wawancara juga dilakukan bersama 1 partisipan informan kunci dari Poli Paru RSUD. Prof. Dr. H. Aloei Saboe Kota Gorontalo. Situasi tempat penelitian aman dan mendukung selama proses wawancar dilaksanakan.

Tema 1 Ungkapan Perasaan Menolak Terhadap Diagnosa MDR-TB

Pengalaman informan yang dirasakan dalam penelitian ini berespon menolak keadaannya terhadap diagnosis MDR-TB. Tema ini terdiri dari sub tema menyangkal masalah dan depresi dengan kategori tidak percaya dan putus asa.

Tema 2 Ungkapan Perasaan Menerima Terhadap Diagnosa MDR-TB

Pengalaman informan yang dirasakan dalam penelitian ini berespon menerima keadaannya terhadap diagnosis MDR-TB. Tema ini terdiri dari sub tema menerima keadaan sakit dengan kategori pasrah dan bersyukur.

Tema 3 Mengalami Efek Samping Pengobatan MDR-TB

Informan mengungkapkan mengalami efek samping dalam menjalani pengobatan MDR-TB. Tema ini terdiri dari sub tema efek dengan kategori nyeri, gangguan pola tidur, gangguan pola makan, ganguan penglihatan, gangguan pendengaran, istirahat/tidur dan nutrisi.

Tema 4 Kepatuhan Terhadap
Pengobatan MDR-TB
Informan
kepatuhan dalam menjalani pengobatan MDR-TB. Tema ini terdiri dari sub tema 
menejemen obat dengan kategori terpaksa dan patuh.

\section{Tema 5 Kesulitan Dalam Menjalani Pengobatan MDR-TB}

Informan mengungkapkan

kesulitan dalam menjalani pengobatan MDR-TB. Tema ini terdiri dari sub tema masalah pelayanan kesehatan, masalah fisik, masalah psikologis, stigma dan masalah finansial. dengan kategori jarak pelayanan kesehatan, aktivitas terbatas, perlakuan tidak baik, dan keuangan.

\section{Tema 6 Dukungan yang Diterima} Selama Menjalani Pengobatan

Dukungan yang diterima selama menjalani pengobatan MDR-TB berasal dari keluarga yang terus mendukung dan selalu memberi dorongan berupa motivasi dalam menjalani pengobatan MDR-TB. Disamping itu informan juga mengatakan mendapat dukungan dari petugas pelayanan kesehatan di ruang G4 Tropik/isolasi dan poli paru RSUD. Prof. Dr. H. Aloei Saboe Kota Gorontalo. Dukungan tersebut berupa pemberian pelayanan yang baik, pemberian konseling informasi dan edukasi selama informan menjalani pengobatan MDR-TB. Tema ini terdiri dari sub tema dukungan keluarga dan dukungan petugas pelayanan kesehatan.

\section{Tema 7 Harapan untuk Mencapai Kesembuhan}

Harapan Informan untuk mecapai kesembuhan setelah menjalani pengobatan MDR-TB berasal dari dalam diri sendiri. Informan selalu berinisiatif untuk menyelesaikaan pengobatan MDR-TB. Harapan tersebut muncul setelah beberapa bulan menjalani pengobatan MDR-TB dirasakan perubahan gejala-gejala sudah mulai berkurang. Tema ini terdiri dari sub tema harapan diri sendiri.

\section{Pembahasan}

\section{Tema 1 Ungkapan Perasaan Menolak Terhadap Diagnosa MDR-TB}

Pada penelitian ini respon pertama kali terdiagnosa MDR-TB yaitu perasaan menolak. Setiap orang akan memberikan reaksi yang berbeda saat mengetahui dirinya terdiagnosa MDR-TB. Hal ini sesuai dengan teori stages of dying oleh Kubbler-Ross (1969) bahwa lima tahapan proses berduka yaitu menolak, marah, tawar-menawar, depresi, menerima. Dalam fase ini, pasien percaya bahwa kehilangan telah terjadi, tidak siap menghadapi masalah-masalah yang terjadi, reaksi denial berlangsung segera 24 jam setelah terjadinya kehilangan.

Fenomena yang terjadi saat menerima kenyataan dirinya sudah terdiagnosa MDR-TB memberikan reaksi menyangkal pada informan baru pertama kali terdiagnosa MDR-TB melalui ungkapan tidak percaya. Hal ini terjadi karena adanya perbedaan perasaan yang dirasakan ketika awal menjalani pengobatan kategori 1 yakni pemberian obat minum selama 6 bulan dilanjutkan pengobatan kategori 2 yakni pemberian suntikan selama 2 bulan ditambah pemberian obat minum selama 6 bulan, sebelum didiagnosa MDR-TB. Perasaan yang dialami berkaitan dengan pengobatan MDR-TB dengan dosis obat yang diberikan lebih dari kategori 1 dan kategori 2 memerlukan jangka waktu selama 2 tahun dimana dosis obat 12 tablet harus diminum setiap hari. Saat ini dirinya tidak percaya karena respon tersebut merupakan respon alamiah yang terjadi 
selama proses berduka pada awal terdiagnosa MDR-TB. Pada saat yang sama individu belum bisa menerima kondisinya.

Hal ini dipertegas oleh pendapat Hudak dan Gallo (1997 dalam Suratini, 2011) menyatakan bahwa respon psikologis seseorang terhadap kehilangan adalah terkejut, pada tahap ini individu mengalami masalah atau kehilangan akan berperilaku menghindar atau menolak. Pada tahap ini individu gagal memahami makna rasional dan dampak emosional dari diagnosa yang dialami.

Informan saat pertama kali terdiagnosan MDR-TB juga mengungkapkan perasaan depresi sehingga digambarkan melalui reaksi putus asa, merasa berat menerima kenyataan bahwa kondisi dialami dirinya terdiagnosa MDRTB. Ketika timbul gejala fisik yang baru, tidak merasakan progrestifitas pengobatan MDR-TB sehingga membuat dirinya semakin sedih seolah harapan hidup dan masa depan sudah tidak ada lagi. Sedangkan perasaan yang berat pula diterima pada awal divonis harus menjalani pengobatan kategori 1 dan kategori 2 selama 6 bulan berturut dengan dosis obat yang tinggi diterima oleh tubuh sebelum didiagnosa MDR-TB dibebankan kepada dirinya.

Hal ini didukung oleh pendapatnya Vinen (2002 dalam Suratini, 2011) menyatakan bahwa pada tahap depresi individu akan mengalami disorganisasi dan merasa tidak mampu melakukan tugas dengan sedikit kesulitan. Orang pada tahap ini akan memiliki kesedihan yang mendalam.

Hal ini juga didukung oleh pendapat Astutin dan Wheller (2000 dalam
Suratini, 2011) juga mempekuat temuan peneliti, dengan menyatakan depresi aktif atau exogenous sebagai salah satu normal grief reactiondan atau yang dikenal reaksi normal atas kehilangan, depresi ini berasal dari faktor luar, biasanya sebagai respon dari kehilangan sesuatu atau seseorang.

Hal ini juga di dukung oleh teori yang di ungkapkan oleh Smeltzer-Bere (2002 dalam Suratini, 2011) bahwa menemukan koping negatif penyangkalan (avoidance) yaitu menerima atau menghargai keseriusan penyakit. Biasanya orang yang sakit menyamarkan gejala yang merupakan bukti suatu penyakit dan mengacuhkan beratnya diagnosis penyakit dan menyangkal. Selain itu klien biasanya menyalahkan diri sendiri (self-blame). Koping ini berupa keputusasaan klien. Klien merasa bersalah terhadap hal yang terjadi akibat perbuatannya. Klien juga mengalam pasrah (wishfull thingking). Klien merasa pasrah terhadap hal yang menimpanya tanpa ada usaha dan motivasi untuk sembuh dari sakitnya.

\section{Tema 2 Ungkapan Perasaan Menerima Terhadap Diagnosa MDR-TB}

informan sudah menerima konseling informasi dan edukasi tentang pengobatan MDR-TB dari tenaga kesehatan, dokter ataupun perawat, dan akhirnya mereka memahami, menyadari ataupun menerima status MDR-TB dan bersedia menjalani pengobatan.

Sejalan dengan Jacob, Knick and Sally (2003) bahwa fase Acceptance/menerima dicapai oleh individu dalam rentang waktu yang bervariasi tergantung dari kemampuan individu membentuk koping menjalani proses berduka. individu beradaptasi 
dalam waktu 1-3 bulan setelah peristiwa kehilangan, namun beberapa individu lain mencapainya dalam 6 bulan hingga 1 tahun (dalam Rahayu, 2008).

Menurut hasil penelitian Nursalam (2011) tentang pengaruh strategi koping terhadap respon penerimaan menunjukkan bahwa kemarahan dan bergaining sangat dipengaruhi oleh strategi koping. Selain itu hasil penelitian ini didukung oleh teori Kubler-Ross yang menyatakan bahwa pada tahap penerimaan individu menyadari bahwa hidup harus tetap berlajut dan mereka harus mencari makna baru dari keberadaan mereka. Pikiran yang selalu berpusat pada obyek atau orang yang hilang mulai berkurang atau menghilang. Individu telah menerima kenyataan kehilangan dialaminya, gambaran tentang obyek atau hilang mulai dilepaskan dan secara bertahap perhatian dialihkan pada obyek yang baru. Seseorang pada tahap ini mulai menyusun rencana yang akan dilakukan pasca kehilangan.

\section{Tema 3 Mengalami Efek Samping Pengobatan MDR-TB}

Efek samping obat dialami semua informan pada awal menjalani pengobatan MDR-TB selama 1 sampai 2 bulan. Efek samping yang dialami informan seperti nyeri persendian, gangguan pola tidur, gangguan pola makan, gangguan penglihatan terlihat kabur, dan gangguan pendengaran atau tuli. Selain itu, memasuki bulan ke 3 dampak positif menjalani pengobatan MDR-TB menunjukkan perubahan kebutuhan istrahat/tidur dan kebutuhan nutrisi lebih baik.

Menurut Nawas (2010) bahwa efek samping MDR-TB seperti kulit dan mata pasien nampak kuning, pendengaran berkurang (tuli), halusinasi, delusi/waham, bingung. Reaksi alergi berat yaitu Syok anafilaktik dan angionerotik edema, kemerahan pada mukosa seperti mulut, mata dan dapat mengenai seluruh tubuh. Efek samping ringan dan sedang tanpa harus menghentikan pengobatan, seperti kemerahan (rash) ringan, neuropati perifer, mual muntah, diare, sakit kepala, gangguan tidur, depresi.

Hal ini sesuai dengan TB indonesia (2011) mengemukakan bahwa efek samping pengobatan menimbulkan gejala berupa mual, muntah, anoreksia, malaise, lemah, gangguan saluran pencernaan lain, neuritis perifer, neuritis optikus, reaksi hipersensitifitas, demam, ruam, ikterus, sakit kepala, ngantuk, mulut kering, gejala rematik. rifampicin dan pirazinamid menyebabkan efek samping yang parah pada lever.

Keluhan yang dirasakan oleh lima partisipan akibat efek samping obat negatif tidak sesuai dengan penelitian diatas karena keluhan yang berhubungan dengan kerusakan fungsi hati seperti ikterik tidak dirasakan pada klien.

Selain itu, pada awal bulan ke 3 dan seterusnya terjadi perubahan kebutuhan istirahat/tidur dan kebutuhan nutrisi yang baik. Hal ini sesuai dengan Janmeja (2005) mengidentifikasi bahwa intervensi psikologis yang efektif dapat meningkatkan kepatuhan dalam menjalani pengobatan dan dapat mengurangi timbulnya kegagalan kambuh serta resistensi obat.

Menurut Tupasi et, al (2017) Multidrug-resistant tuberculosis patients' views of interventions to reduce treatment loss to follow-up menghasilkan tema yaitu 
kebutuhan transportasi, bantuan makanan, dan kesulitan pasien ditemui terkait dengan obat mereka. Pendekatan lebih berpusat pada pasien terkait kebutuhan diperlukan untuk memperbaiki kepatuhan pengobatan MDR-TB. Bantuan program harus berusaha untuk diberikan dengan mempertimbangkan preferensi pasien, sebagian untuk menutupi kebutuhan aktual.

Dampak positif dari pengobatan adalah kebutuhan istirahat/tidur tidak terganggu. Waktu untuk tidur selama 5 sampai 7 jam sehari. Hal ini terjadi pada bulan ke 3 selama menjalani pengobatan MDR-TB. Menurut Rejeki (2011) faktor yang mempengaruhi kualitas dan kuantitas tidur adalah penyakit, lingkungan, kelelahan, gaya hidup, stress emosional, dan alkohol, diit, merokok, motivasi.

Hal ini sejalan dengan hasil penelitian Sarmiaaji (2010) menemukan pengalaman efek samping mempunyai kecenderungan lebih besar untuk melaksanakan kepatuhan yang tinggi dari pada yang tidak memiliki pengalaman efek samping pengobatan. Apabila pada awal terapi tidak diberikan edukasi tentang efek samping obat sehingga tidak mengetahui penanggulangan serta soft skill tentang koping yang efektif guna menanggulangi efek samping.

\section{Tema 4 Kepatuhan Terhadap Pengobatan MDR-TB}

Selama menjalani pengobatan MDR-TB informan menunjukkan sikap kepatuhan terhadap pengobatan. Saat ini informan mempertahankan kepatuhan menjalani pengobatan MDR dengan mendapatkan dukungan dari keluarga dan petugas pelayanan kesehatan. Hal ini didukung oleh Masniari (2007) mengidentifikasi faktor yang mempengaruhi kesembuhan penyakit TB antara lain faktor individu, komunitas, kepatuhan, strategi pengobatan dan keadaan khusus seperti merokok, alkohol, tunawisma.

Menejemen obat MDR-TB juga dilakukan lima informan sesuai dosis pemberian selama menjalani pengobatan MDR-TB. Lima informan telah memiliki pengetahuan tentang pengobatan MDRTB. Dalam sehari informan menghabis obat oral sebanyak 12 tablet dengan waktu minum obat secara teratur di tambah suntikan. Pemberian konseling, informasi dan edukasi tentang obat MDR-TB telah mereka dapatkan selama melakukan pengobatan di rumah sakit. Hal ini didukung oleh Cramm (2010) menemukan bahwa motivasi individu dan percaya diri yang kuat akan berpengaruh terhadap kepatuhan.

Selama menjalani pengobatan MDR-TB informan mengalami beberapa hal mempengaruhi persepsi dirinya terhadap penyakit. Informan mengungkapkan tantangan efek samping obat dan menejemen obat yang didapatkan selama menjalani pengobatan MDR-TB. Tetapi dari tantangan yang dialami, informan masih berkomitmen untuk terus melakukan pengobatan dengan harapan untuk kesembuhan dari penyakitnya.

Hal ini sesuai dengan Naidoo (2008) faktor yang mempengaruhi kepatuhan adalah sumber daya sosial dan ekonomi, sosial budaya, ekonomi, tantangan terkait, psikologis yang dihadapi sebagai konsekuensi dari penyakit TB yang dialami, kualitas pelayanan kesehatan yang diterima penggunaan sistem kesehatan tradisional dan para peserta 
status HIV. Tantangan berat yang dihadapi klien adalah tekanan psikologis dari penyakitnya dan pengobatan yang dijalani.

\section{Tema 5 Kesulitan Dalam Menjalani Pengobatan MDR-TB}

Semua informan dalam penelitian ini merasakan kesulitan yang sama. Kesulitan yang dialami dari program pengobatan MDR-TB menyebabkan seluruh aspek kehidupan maupun aspek kesehatan semakin terpuruk, sehingga dapat mempengaruhi kualitas hidup mereka. Lima Informan mengungkapkan kesulitan yang dialami dalam menjalani pengobatan MDR-TB adalah jarak pelayanan kesehatan, aktivitas terbatas, stressor sosial dan keuangan.

Sejalan dengan teori Morris et, al (2013) bahwa beberapa pasien mampu mempertahankan TB pra MDR-TB mereka sampai batas waktu tertentu, kebanyakan pasien melaporkan kehilangan identitas karena ketidakmampuan mereka untuk bekerja, isolasi sosial, stigmatisasi dari keluarga, teman dan lingkungan. Didiagnosis TB-MDR dan pengobatan yang dijalani menimbulkan tekanan psikologis, sosial dan ekonomi yang signifikan dialami oleh pasien.

Jarak yang ditempuh informan ke pelayanan kesehatan merupakan lain yang dirasakan informan karena setiap hari datang untuk berobat ke rumah sakit. Menurut O'Boyle (2002 dalam Rejiki, 2011) kepatuhan dapat ditingkatkan dengan peningkatan edukasi penderita, keluarga dan populasi umum, mengurangi biaya transportasi dan lamanya perjalanan. Namun belum ada tempat pengobatan MDR-TB selain di Poli Paru RSUD. Prof. Dr. H. Aloei Saboe Kota Gorontalo sehingga semua informan berkomitmen walaupun jarak yang jauh ditempuh untuk menjalani pengobatan MDR-TB.

Kesulitan yang dialami informan yaitu masalah fisik menyebabkan aktivitas terbatas karena kondisi penyakitnya sehingga belum bisa beraktifitas seperti orang lain pada umumnya. Mereka merasakan saat beraktifitas sedikit saja sudah lelah ini mengakibatkan hilangnya pekerjaan mereka dan membutuhkan bantuan berobat ke rumah sakit karena klien mengalami ketidakcukupan energi untuk melanjutkan atau menyelesaikan aktifitas kehidupan sehari-hari yang harus dilakukan akibat respon pulmonal (Nanda, 2009-2011). Masalah intoleransi aktifitas ini diatasi mereka hanya dengan istirahat dan tidak melakukan pekerjaan.

Stigmatisasi yang meliputi perlakuan tidak baik, konflik yang terjadi karena omongan orang yang menyakitkan, harus selalu ingat untuk minum obat, konflik ini diatasi klien dengan sabar dan berserah diri pada yang kuasa.

Janmeja (2005) melakukan penelitian bahwa intervensi psikologis yang efektif dapat meningkatkan kepatuhan klien dalam menjalani pengobatan TB. Keluhan psikologis yang dialami klien dapat diatasi dengan pemberian konseling informasi dan edukasi terus menerus yang dilakukan oleh petugas kesehatan.

Kesulitan lainnya dialami adalah masalah finansial selama menjalani pengobatan MDR-TB sehingga mereka tidak dapat bekerja. Informan mengatakan bahwa keuangan menjadi masalah nomor satu. Obat MDR-TB diberikan secara gratis dan pemeriksaan laboratorium dan pemeriksaan penunjang lainnya juga ditanggung oleh rumah sakit akan tetapi 
mereka sudah tidak bekerja memerlukan bayaran tambahan untuk memenuhi kebutuhan hidup.

Menurut Erawatiningsih (2009) pendidikan, pengetahuan dan pendapatan keluarga berpengaruh negatif terhadap ketidakpatuhan berobat pada penderita TB. kesulitan yang dirasakan oleh informan sesuai dengan penelitian ini sangat memberatkan informan. Untuk membantu kesulitan finansial yang dialami oleh klien MDR-TB, para pengambil kebijakan bisa membantu mengalokasikan dana untuk pemeriksaan yang berkaitan dengan klien MDR-TB digratiskan.

Meskipun pengobatan MDR-TB gratis tapi penghasilan keluarga kurang tidak seperti dulu lagi saat memiliki pekerjaan. Hal ini yang memberatkan mereka selama menjalani pengobatan tidak bekerja dan harus menanggung kebutuhan keluarga. Namun pelayanan kesehatan sudah baik dan petugas sangat aktif dalam memberikan pelayanan kesehatan selama menjalani pengobatan MDR-TB.

\section{Tema 6 Dukungan yang Diterima Selama Menjalani Pengobatan}

Selama menjalani pengobatan

MDR-TB semua informan mendapatkan dukungan dari keluarga dan dukungan petugas pelayanan kesehatan. Mereka mendapat dukungan informasional, dorongan berobat dari istri, anak, kakak ipar, mendapatkan support, mengingatkan untuk minum obat secara rutin dan nasehat menjalani pengobatan dengan baik serta pelayanan kesehatan baik. Menurut Tahan (2004) dukungan keluarga dapat meningkatkan kepatuhan minum OAT penderita TB paru. Friedman (1998) keluarga mempunyai fungsi dukungan antara lain dukungan informasional, penilaian, instrumental dan emosional. Keluarga merupakan merupakan faktor pendukung utama dalam kesembuhan.

Hal ini sesuai dengan pendapat Dong dan Naruemol (2007 dalam Rejeki, 2011) mengidentifikasi bahwa keluarga membantu klien TB untuk mengatasi kesulitan termasuk meminta bantuan keluarga, teman dan petugas kesehatan. Klien TB mengharap dukungan dan pengertian dari keluarganya karena menjalani pengobatan lama juga berdampak terhadap keluarganya, termasuk sumber dana digunakan untuk keluarga.

Dukungan juga diterima informan dari petugas pelayanan kesehatan yang lebih banyak memberikan konseling, edukasi dan informasi tentang penyakit MDR-TB, penularan, pengobatan dan tidak kambuh lagi dengan memberi nasehat dan saran yang baik.

Sejalan dengan pendapat Helvi (1998) salah satu peran perawat komunitas adalah sebagai konselor. Anderson dan Mc. Farlan (2004) pelayanan keperawatan komunitas bertanggung jawab terhadap peningkatan kesehatan masyarakat terutama kelompok masyarakat yang kurang mendapat perhatian.

Selan itu, Murray (2010) mengemukakan bahwa petugas kesehatan sudah memberikan informasi tentang gejala utama penyakit TB dan memberi nasehat penyakit TB bisa disembuhkan. Dalam penelitian ini klien sudah mendapat informasi tentang TB tapi informasi yang didapatkan kurang jelas dan lupa sehingga perlu metode promosi kesehatan yang mudah diingat oleh klien.

Tema 7 Harapan untuk Mencapai Kesembuhan 
Harapan semua informan ingin sembuh dan bisa kerja lagi untuk menanggung ekonomi keluarga, serta menyelesaikan pengobatan. Namun kondisi yang lemah menyebabkan mereka tidak bekerja. Semua informan dalam menjalani pengobatan MDR-TB berharap bisa sembuh total dan tidak kambuh lagi. Kekambuhan dialami karena kondisi tubuh yang lemah, kelembaban kamar tidur, ventilasi kamar kurang dan tempat tinggal tidak terpapar sinar matahari.

Menurut Rusnoto (2008) faktor yang berpengaruh terhadap kejadian TB paru adalah kelembaban kamar tidur, ventilasi kamar tidur, riwayat penularan anggota keluarga, status gizi rendah dan tingkat pengetahuan. Pengalaman klien pernah mengalami kekambuhan dan merasakan beratnya menjalani pengobatan yang lama, klien berharap kesembuhan total dan sehat untuk selamanya. Penelitian di RS Persahabatan (1998) proporsi kesembuhan penderita TB-MDR sebesar $72 \%$ menggunakan paduan OAT yang masih sensitif ditambah ofloksasin.

Selain itu, Soepandi (2010) menyatakan bahwa penatalaksanaan TB harus sesuai dengan guideline; dosis, regimen dan lama pengobaatan yang tepat serta jangan lupa menerapkan strategi DOTS. Hal ini akan meningkatkan angka kesembuhan serta mencegah resistensi. Jika ditemukan kasus yang dicurigai resisten segera lakukan pemeriksaan biakan dan uji kepekaan. Pada pengobtan TB-MDR harus menerapkan strategi DOTS-PLUS.

Menurut peneliti, selama berjalannya program pengobatan MDR-TB yang dijalani informan sampai saat ini mampu menekan gejala penyakit. Dengan ini informan berkomitmen untuk tetap menjalankan pengobatan hingga selesai pengobatan MDR-TB. Beberapa motivasi diri yang dilakukan informan tetap konsisten dalam pengobatan MDR-TB mulai ditampakkan bahkan keinginan untuk tetap sembuh dari penyakit ini. Maka dengan berakhirnya program pengobatan MDR-TB yang dijalankan semua informan, semua aspek kehidupan dan kesehatan kembali sama seperi orang normal.

\section{SIMPULAN}

Perasaan informan pertama kali terdiagnosa penyakit MDR-TB menggambarkkan respon menolak pada saat mengetahui dirinya terdiagnosa MDRTB. Fenomena yang terjadi saat menerima kenyataan dirinya sudah terdiagnosa MDR-TB memberikan reaksi menyangkal pada informan baru pertama kali terdiagnosa MDR-TB melalui ungkapan tidak percaya dan putus asa.

Informan ketika sudah menerima konseling informasi dan edukasi tentang pengobatan MDR-TB dari tenaga kesehatan dokter ataupun perawat pada akhirnya mereka memahami, menyadari ataupun menerima status MDR-TB dan bersedia menjalani pengobatan di rumah sakit bahwa konsekuensi harus mereka terima penuh dengan sikap terbuka selama menjalani pengobatan MDR-TB.

Efek samping obat terjadi pada awal menjalani pengobatan MDR-TB selama 1 sampai 2 bulan dan setelah memasuki bulan ke 3 dampak positif menjalani pengobatan MDR-TB menunjukkan perubahan kebutuhan istrahat/tidur dan kebutuhan nutrisi menjadi lebih baik dari sebelumnya. 
Kepatuhan dalam mejalani pengobatan MDR-TB saat ini informan berkomitmen mempertahankan kepatuhan menjalani pengobatan MDR dengan mendapatkan dukungan dari keluarga dan petugas pelayanan kesehatan.

Kesulitan dalam menjalani pengobatan MDR-TB adalah jarak pelayanan kesehatan, aktivitas terbatas, stressor sosial dan keuangan menyebabkan seluruh aspek kehidupan maupun kesehatan semakin terpuruk, sehingga dapat mempengaruhi kualitas hidup mereka.

Informan mendapatkan dukungan yang diterima berasal dari keluarga berupa dukungan informasional, dorongan berobat dari istri, anak, kakak ipar, dukungan penilaian informan mendapatkan support dan mengingatkan untuk minum obat secara rutin, nasehat menjalani pengobatan dengan baik. Selain itu, dukungan petugas pelayanan kesehatan lebih banyak memberikan konseling, edukasi dan informasi tentang penyakit MDR-TB, penularan, pengobatan dan tidak kambuh lagi dengan memberi nasehat dan saran yang baik,

Harapan informan ingin kembali seperti dulu bisa kerja lagi untuk menanggung ekonomi keluarganya, menuntaskan pengobatan yang lama dialaminya namun kondisi yang lemah menyebabkan mereka tidak bisa kerja lagi.

\section{DAFTAR PUSTAKA}

Afiyanti, Y. dan I. N. Rachmawati. 2014. Metodologi Penelitian Kualitatif Dalam Riset Keperawatan. Rajawali Pers. Jakarta.
Alfin, S. 2010. Multi drug Resistant Tuberculosis (MDR-TB). Tinjauan Kepustakaan. Fakultas Kedokteran Universitas Syiah Kuala Aceh.

Anderson, E.T., McFarlane, J. 2006. Buku ajar keperawatan komunitas. Teori dan praktik. Community as partner. Theory and practice in nursing. Terjemahan Agus Sutarna, Suharyati Samba,Novayantie Herdina. Edisi ke 3. EGC. Jakarta.

Anggraeni dan Saryono. 2011. Metodologi Penelitian Kualitatif Dalam Riset Keperawatan. Nuha Medika. Yokyakarta.

Blondal, K. et.al. 2013. Overall and causespecific mortality among patients with tuberculosis and multidrugresistant tuberculosis. The International Journal of Tuberculosis and Lung Disease. 17(7):961-968.

Burhan, E. 2010. Peran ISTC dalam Pencegahan MDR. Jurnal Tuberculosis Indonesia.7:18295118

Cramm, J.M, at al. 2010. Patient View on Determinants of Complience with Tuberculosis treatment in the Eastern Cape. An Aplication of di Methodology. South Africa.

Darmawan, R. 2013. Pengalaman, Usability, dan Antarmuka Grafis. Institut Teknologi Bandung Jurnal. 4(2): 95-102

Dinas Kesehatan Propinsi Gorontalo. 2017. Jumlah Kasus MDR-TB Propinsi Gorontalo. P2MPL. Gorontalo.

Dulahu. Wirda 2013. Studi fenomenologi : pengalaman menjadi Perawat baru di ruang perawatan intensiv Rs. 
Universitas Hasanuddin. Tesis. Program pasca sarjana. Makassar.

Elmi,O,S. et. al. 2016. Treatment Outcomes of Patients with Multidrug-Resistant Tuberculosis (MDR-TB) Compared with NonMDR-TB Infections in Peninsular Malaysia. The Malaysian Journal of Medical Sciences. 23(4): 17-25.

Erawatyningsih, E. 2009. Faktor-Faktor yang Mempengaruhi

Ketidakpatuhan Berobat pada Penderita TB paru. Berita Kedokteran Masyarakat Vol. 25, No. 3, September 2009 halaman $117-124$

Friedman, M.M. 1998. Family Nursing: Theory and Practice. Original English Language Edition Published

Helvie. 1998. Advanced practice nursing in the community. SAGE Publications. Inc. California.

Hudoyo, A. 2010. Faktor Risiko MDR-TB

Di Indonesia: Spesifik dan khas Indonesia. IAAT. Jurnal Tuberculosis

Indonesia.12(7):1829-5118

Janmeja, A. K. 2005. Psychotherapy Improves Complience with Tuberculosis Treatment. Department of Pulmonary Medicine, Government Medical College. Chandigarh. India.

Kementrian Kesehatan RI. 2016. Tuberkulosis Temukan Obat Sampai Sembuh. Ditjen Pencegahan dan Pengendalian Penyakit. Jakarta.

Kementrian Kesehatan RI. 2014. Petunjuk Teknis Manajemen Terpadu Pengendalian Tuberkulosis
Resistan Obat. Ditjen Pengendalian Penyakita dan Penyehatan Lingkungan. Jakarta.

Kubbler, Ross. 1969. On death and dying. Scribner. New York.

Masniari L, Priyanti ZS, Aditama TY. 2007. Faktor-Faktor yang Mempengaruhi

Kesembuhan Penderita TB Paru. Jurnal

Tuberculosis Indonesia. 7:1829-5118

McMurray., Anne. 2003. Community health and wellness: Asocioecological approach. Edisi ke 2. Elsevier. Mosby.

Morris, M. D. et. al. 2013. Social, economic, and psychological impacts of MDR-TB treatment in Tijuana, Mexico: azpatient's perspective. The International Journal of Tuberculosis and Lung Disease. 17(7):954-960.

Naidoo, P., Dick, J., Cooper D. 2008. Exploring Tuberculosis Patients Adherence to Treatment Regimens and Prevention Programs. Department of Psychology, University of the Western Cape, Bellville, South Africa.

NANDA International. 2011. Diagnosis Keperawatan, Definisi dan Klasifikasi 2009-2011. Cetakan I. EGC. Jakarta.

Nawas. 2010. Penatalaksanaan TB-MDR Dan Strategi Dots Plus. Jurnal Tuberculosis Indonesia.7:18295118.

Nursalam. 2011. Model asuhan keperawatan terhadap peningkatan adaptasi kognisi dan biologis pada pasien terinveksi hiv. Jurnal Ners. 6:113-125 
Rahayu. 2008. Respon dan Koping Ibu dengan Kematian Janin: Studi Grounded Theory. Tesis. Program Pasca Sarjana. Universitas Indonesia. Jakarta.

Rejeki. 2012. Pengalaman Menjalani Pengobatan TB Kategori II di Wilayah Kabupaten Pekalongan Jawa Tengah. Tesis. Program magister ilmu keperawatan UI. Depok.

Rusnoto. 2008. Faktor-faktor yang Berhubungan dengan Kejadian TB Paru pada Usia Dewasa. Studi kasus di Balai Pencegahan Dan Pengobatan Penyakit Paru Pati.Tesis. Fakultas Kedokteran Bagian Penyakit Dalam. Program Studi Magister Epidemiologi. Program Pascasarjana. UNDIP

Sarmiaaji. 2010. Kepatuhan pasien HIV/AIDS terhadap terapi Antiretroviral di RSUP Dr. Karyadi semarang. Jurnal. promosi kesehatan indonesia. 5:1.

Soepandi, P.Z. 2010. Diagnosis dan Faktor yang Mempengaruhi TB-MDR. Jurnal Tuberculosis Indonesia. 7:1829-5118

Sjahrurachman, A. 2010. Diagnosis "Multi Drug Resistant Mycobacterium" Tuberculosis. IAAT. Jurnal Tuberculosis

Indonesia.12(7):1829-5118

Susilo, W.H., C.I. Kusumaningsih, H. Aima, dan J. Hutajulu. 2015. Riset Kualitatif \& Aplikasi Penelitian Ilmu Keperawatan. CV. Trans Info Media. Jakarta Timur.

Suratini. 2011. Pengalaman orang dengan hiv/aids (odha) Mendapatkan perawatan keluarga Di wilayah kabupaten kulon progo Daerah istimewa yogyakarta Studi fenomenologi. Universitas Indonesia. Tesis. Program Magister Keperawatan. Depok

Syahrini, H. 2008. Tuberkulosis Paru Resisten Ganda. Disertasi. Departemen Penyakit Dalam. Fakultas Kedokteran Sumatera Utara.

Tahan, P.H. 2004. Pengaruh Dukungan Keluarga terhadap Kepatuhan Minum Obat anti TB. Jurnal Ilmiah Kesehatan.4:1

TBIndonesia. 2011. Penanggulangan Tuberkulosis Terpadu. Ditjen Pengendalian Penyakita dan Penyehatan Lingkungan. Jakarta.

The Indonesian Association Againts Tuberculosis. 2010. Jurnal Tuberkulosis Indonesia. PPTI. Jakarta.

Tupasi, T. et, al. 2017. Multidrug-resistant tuberculosis patients' views of interventions to reduce treatment loss to follow-up. The International Journal of Tuberculosis and Lung Disease. 21(1):23-31.

World Health Organization Region. 2015. Laporan Tuberkulosis Global 2016.

15 Juli 2017 (11.00)

Xua B, et, al. 2004. Perceptions and experiences of health care seeking and access to TB care--a qualitative study in Rural Jiangsu Province, China.

http://www.sciencedirect.com/scien celarticle/pii/S0168851004000776 12 September 2017 (19.00) 
Zhang, et al. 2010. A Qualitative Study The Experience of College Students With Pulmonary Tuberculosis in Shaanxi. China. http://www.biomedcentral.com/147 1-2334/10/174 11 Juli 2017 (14.00) 